\title{
Factors Related to Citing from Preceptorship Competence: A Systematic Review
}

\section{Fitri Chandra1, Nursalam2, Slamet Riyadi Yuwono3}

1. Mahasiswa Fakultas Keperawatan Universitas Airlangga

2. Fakultas Keperawatan Universitas Airlangga

3. Kementrian Kesehatan Indonesia

\section{Riwayat artikel}

Diajukan: 3 Agustus 2019

Diterima: 28 Maret 2020

\section{Penulis Korespondensi: \\ - Nursalam \\ - Fakultas Keperawatan, Universitas Airlangga nursalam@fkp.unair.ac.i d}

\section{Kata Kunci:}

Preceptorship, preceptor, competency

\begin{abstract}
Introduction Preceptorship is a learning method that involves more experience in conveying their knowledge to someone who is less experienced. In this article, the authors conducted a relevant systematic review in various data used the keywords "preceptorship,"transition and article thinking". Data based on SCOPUS, Science Direct, Proquest, Pubmed, and Google Scholar. The criteria consisted of the full text published in five years limit journal (2013-2018) and used the article in English. The results as much as 1517 articles found, and selected 15 article that suitable with criteria. Aim: The purpose of this study is to analyze factors that affect the implementation of preceptorship in the hospital and to give the recommendation of monitoring and evaluation preceptorship as well. Method: Papers were critically reviewed and relevant data were extracted and synthesized using an approach based on preferred reporting items for systematic reviews and Meta-Analysis (PRISMA). Result: These factors include the level of education, experience, support, guiding model, and work environment
\end{abstract}

\section{INTRODUCTION}

Preceptorship is a learning method that involves more experience in conveying their knowledge to someone who is less experienced 1 . A preceptor becomes a model or role model in preceptorship activities while simultaneously providing expert advice to the precepts2. The form of preceptorship is in the form of advice relating to practice in the workplace including role models in one-toone groups and organizations3. Preceptorship is a very important part of a hospital organization that is applied during new employee orientation, mutation, and rotation, as well as guidance for school students who undergo fieldwork practices.

In the implementation of preceptorship, there are often various obstacles among others unrecognized preceptor's guidance schedules that not match with a work time of preceptor unbalanced preceptors ratios with precepts lack of understanding of learning methods and bad work environment4. Based on research at the University of Newcastle, new nurses admitted that they were stressed in adapting, namely a lack of communication with the health team in their new works.

In his study revealed that new nurses after completing the orientation period still need support through the program preceptorship and increasing retention of new nurses by $29 \%$ (from $60 \%$ to $89 \%$ ) and $9,5 \%$ decreasing nurses vacancies6.

Preceptors in hospitals need to carry out an evaluate the implementation because there are still problems with the guidance system, the requirement as a supervisor, besides that it requires as a supervisor, besides that it requires an increase in the quality and competency of the preceptor to produce competent preceptor7.

Based on this phenomenon, the authors are interested in conducting further 
analysis related to various factors that influence the application of preceptorship in his hospitalss. Therefore, this systematic review aims to identify age-friendly health systems for the elderly.

\section{Material and Methods}

This systematic review was reported by the PRISMA (Preferred Reporting Items for Systematic reviews and Meta-Analyses) Statement6.

\subsection{Data Sources and Searches}

Databased searched from SCOPUS, Science Direct, Proquest, Pubmed, and Google Scholar provide studies related to identifying age-friendly health systems for the elderly, determined from 2013 to 2019.

\subsection{Study Selection}

The studies selected by inclusion criteria were open access, cross-sectional and qualitative study with elderly participants, full-text articles, English language and we excluded studies with non-elderly participants, and study protocols.

\subsection{Data extraction and quality assessment}

All citations retrieve from electronic databases that imported to Mendeley Program. Two reviewers (BU, SNK) independently analyzed the titles and abstracts of every study retrieved from the literature search to identify potentially eligible studies. The full text of the remaining studies obtains for further examination. The last review conducted by a first reviewer (TPD).

In this article, the authors conducted a relevant systematic review in variously of data used the keywords "age-friendly", "health system", "elderly". Data of studies were independently extracted by the same two reviewers by including the first author's name, year of publication, sample size, study design, duration of the trial, general characteristics of participants (age and gender). A detail description of age-friendly health system. WHO's guidelines as the main outcome of this systematic review.

\section{Result}

3.1 Study Size

We conducted identification of 567 studies in database sources. Seven duplicate studies were excluded continued by 401 studies due to non-elderly participants, irrelevant studies and study protocols. The six remain studies included in the current systematic review.

\subsection{Study Characteristics}

Data were extracted from each study that needed the requirements. The extracted data included the characteristics of the study, characteristics of the age-friendly health system, characteristics of the results and summary of results.

The Standard protocol for selecting studies as suggested in the systematic review method guide, PRISMA. The steps taken are:

1. Removal of duplication

2. Examination independently of titles, abstracts and keywords and delete citations that were not

relevant according to the inclusion criteria,

3. If the title and abstract likely by the inclusion criteria and the objectives of the systematic review,

the next step was the selection of journals with full text.

4. The final step was the selection of articles

\section{Discussion}

The Study explains the problems that arise in the guidance process of the undergraduate students in hospitals, namely the use of language and instruments that are less objective in evaluating student competencies4.

It Suggests the use of portfolio applications that can be easily accessed by a nursing undergraduate student so that the ease of access makes students motivated in the preceptorship process 9 .

Explained that for postgraduate students, care should be focused on guidance on increasing self-confidence and specific competencies by the specialization of the program10. Explains how to organize and prioritize work, communication, and leadership for postgraduate students.

Based on the research, it can be concluded that the preceptor education level influences the guidance or preceptorship processi1. Preceptors must be able to analyze the competencies that must be achieved by precepts so they can optimize ability, 
creativity, and innovation during the preceptorship period 3

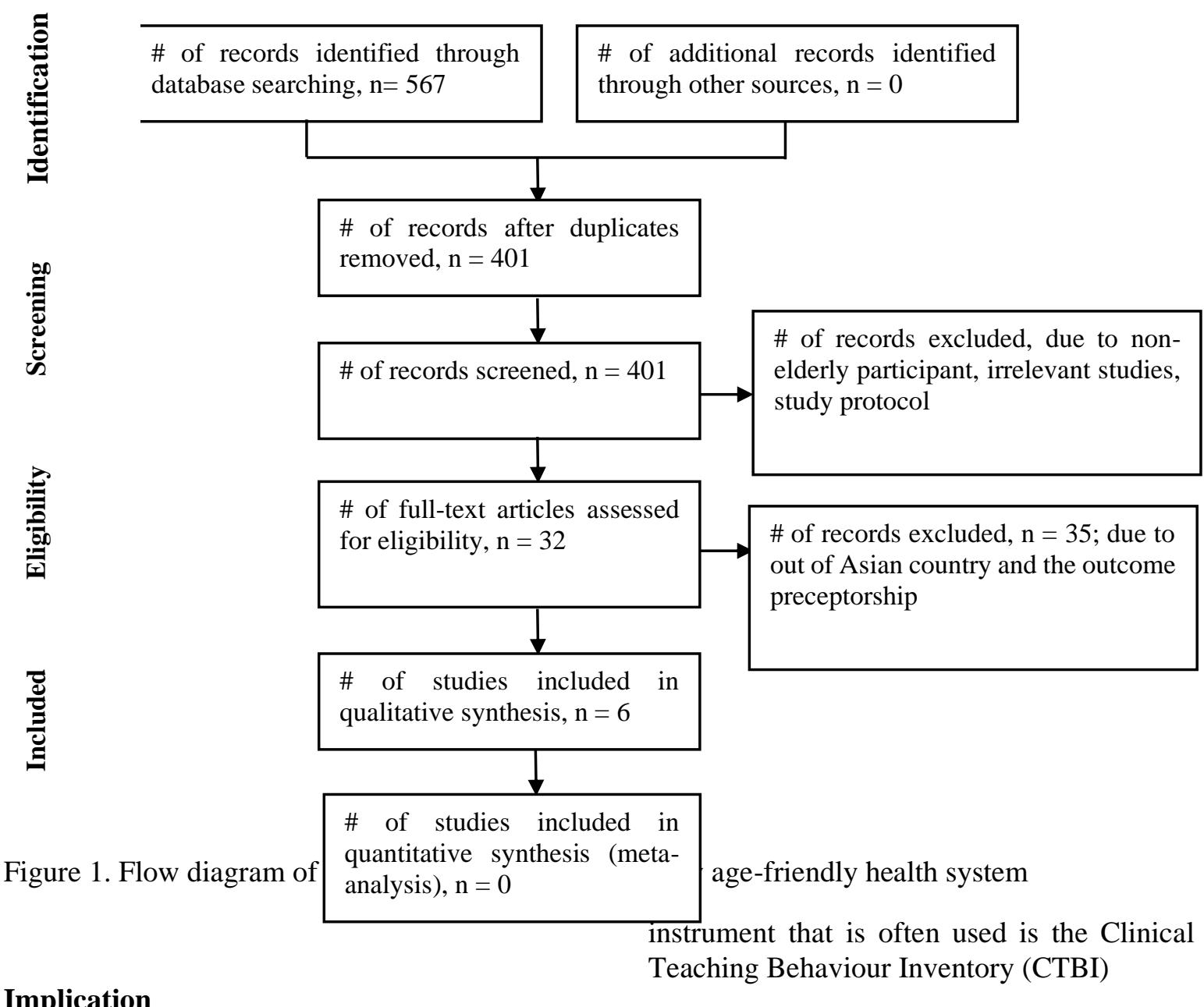

Based on the research, it can be concluded that the work environment has a positive impact on precepts to form a conducive work environment as $\mathrm{s}$ good provision if they become employees in a company.

\section{Conclusion}

Systematic reviews obtained from 15 medical journals showed various factors that influence. These factors include the level of education, experience, support, guiding model, and work environment. The type of 
3.4 Description of the study characteristics, outcome, measurement, interventions and results.

First Author

(Year)
Study

Characteristic

1. Design

2. Sample

(Stone,

Cooper \&

Cant 2013)

Nursing

students

participation

and degree of

involvement in

essential

nursing a

Nursing

standart, 2013)

activities

during their

clinical

practice in

hospital setting

$\begin{array}{ll}\text { (Ravanipour, } & \text { Exporing } \\ \text { Bahreini \& } & \text { nursing student } \\ \text { Ravanipour } & \text { experience of } \\ \text { 2015) } & \text { peer learning } \\ & \text { in clinical } \\ & \text { practice }\end{array}$

(Peyman,

Sadeghifar,

Khajavikhan,

Learning style

preference of

1. Cross sectional

2. Sample

a. Cross

558

: 32

undergraduated
1. Survey

2. 9965
1. Cross Age-friendly

Sectional PHCCs toolkit of

2. 564 the WHO

\section{Outcome and}

Measurement

Age friendly

and Qualitative cities 8 domain

sectional :

b. Qualitative

framework

Intervention

1. Treatment group(s)

2. Type, dose, frequency and administration

method

3. Duration per session/Total number of sessions/Total Duration of intervention

Results

The degree of nursing students involvement in a widw range of nursing activities is related to the year and the discipline of nursing studies
The analysis identified

1.paradoxical dualism

4 themes: exploitation 3 first learningeficecy

4.socialization practice 


\begin{tabular}{|c|c|c|c|c|c|c|}
\hline & $\begin{array}{l}\text { Yasemi, } \\
\text { Rasool, } \\
\text { Yaghoubi, } \\
\text { Mohammad } \\
\text { Hassan Nahal } \\
\text { \& Karim } \\
\text { 2014) }\end{array}$ & $\begin{array}{l}\text { nursing } \\
\text { students }\end{array}$ & & & & \\
\hline 4 & $\begin{array}{l}\text { (Dolotallas \& } \\
\text { Nagtalon } \\
\text { 2015) }\end{array}$ & $\begin{array}{l}\text { The effect of } \\
\text { experiential } \\
\text { learning } \\
\text { approach on } \\
\text { the students } \\
\text { performance in } \\
\text { Filipino }\end{array}$ & Qualitative & $\begin{array}{l}\text { Experiential } \\
\text { learning } \\
\text { students } \\
\text { performance }\end{array}$ & - & $\begin{array}{l}\text { There was a significant difference in } \\
\text { achievement between the experimental } \\
\text { and control group in the first and second } \\
\text { grading }\end{array}$ \\
\hline 5 & $\begin{array}{l}\text { (Chmil, Turk, } \\
\text { Adamson \& } \\
\text { Larew 2015) }\end{array}$ & $\begin{array}{l}\text { Effects on of } \\
\text { an experiential } \\
\text { learning } \\
\text { simulation } \\
\text { design on } \\
\text { clinical nursing } \\
\text { judgment } \\
\text { development }\end{array}$ & Qualitative & $\begin{array}{l}\text { Nursing } \\
\text { judgment } \\
\text { nursing } \\
\text { competence } \\
\text { experiential } \\
\text { learning }\end{array}$ & - & $\begin{array}{l}\text { Using an experiential learning } \\
\text { simulation design results in more highly } \\
\text { developed nursing judgment and } \\
\text { competency in simulation performance }\end{array}$ \\
\hline 6 & $\begin{array}{l}\text { (Manninen } \\
\text { 2016) }\end{array}$ & $\begin{array}{l}\text { Authenticity in } \\
\text { learning } \\
\text { nursing } \\
\text { studdent } \\
\text { experiences at } \\
\text { a clinical } \\
\text { education ward }\end{array}$ & Qualitative & $\begin{array}{l}\text { Students } \\
\text { experiences }\end{array}$ & - & $\begin{array}{l}\text { The most important component in } \\
\text { students learning are mutual } \\
\text { relationship and a sense of } \\
\text { belongingness }\end{array}$ \\
\hline
\end{tabular}




\section{Reference}

Carmel et.al. (2014). How to grow our own: An evaluation of preceptorship in New Zealand graduate nurse programmes. http:// dx. doi. org/10.5172/conu.2013.43.2.162

Chi Pi Chang. et.al. (2016). Clinical nurse preceptors' perception of e-portfolio use for undergraduate students. Journal of Professional Nursing. http://dx.doi.org/

10.1016/j.profnurs.2016.11.001

Chen \& Mei. (2013). The effectiveness and application of mentorship programmes for recently registered nurses: a systematic review. Journal of Nursing Management, 2014, 22, pp 433-442

Eimear et al. (2016). Preceptors' experiences of using a competence assessment tool to_assess undergraduate nursing students. Nurse Education in Practice. $\quad$ http:// dx.doi.org/10.1016/j.nepr.2016.01.00 4

Hellen et al. (2016). Delegation and supervision of healthcare assistants' work in the daily management of uncertainty and the unexpected in clinical practice: invisible learning among newly qualified nurses. Nursing Inquiry 2016, pp 1-9. https://wileyonlinelibrary.com/journa l/nin

Jane Lee-Hsieh. et.al. (2016). The development and validation of the Clinical Teaching Behavior Inventory (CTBI-23): Nurse preceptors' and new graduate nurses' perceptions of precepting. www.elsevier.com/nedt. Nurse Education Today 38 (2016), pp 107-114

Kristiina \& Martha. (2007). Changes in the preceptor role: re-visiting preceptors' perceptions of benefits, rewards, support and commitment to the role. JAN Original research

Lazarus, Judy. (2016). Precepting IOI : Teaching Strategies and Tips For Success Perceptors. Journal of Midwifery \& Women's Health. 15269523/09/\$36.00 doi:10.1111/jmwh.
Mary A et al. (2015). Preceptor Support in Hospital Transition to Practice Programs. The Journal of Nursing Administration (The JONA). 45(12), pp 642-649

Susan \& Chad. (2010). Preliminary outcomes of a local residency programme for new graduate registered nurses. Journal of Nursing Management, 2010, 18, pp 96-104

Susan \& Cinthya (2009). Creating context for critical thinking in practice: the role of the Preceptor. Journal of Advanced Nursing. 65(8), pp 1715-1724. doi: 10.1111/j.1365-2648.2009.05031.x

Anderson, C., Moxham, L. \& Broadbent, M.. (2016). Providing support to nursing students in the clinical environment: a nursing standard requirement. Contemporary Nurse, 52(5), pp.636642.

Carlson, E. \& Bengtsson, M. (2015). Perceptions of preceptorship in clinical practice after completion of a continuous professional development course- a qualitative study Part II. BMC Nursing, 14(1), pp.1-7. http://dx.doi.org/10.1186/s12912015-0092-8.

Haggerty, C., Holloway, K. \& Wilson, D. (2013). How to grow our own: An evaluation of preceptorship in New Zealand graduate nurse programmes. Contemporary Nurse.

Harrison-White, K. \& Simons, J. (2013). Preceptorship: ensuring the best possible start for new nurses. In: Nursing Children and Young People.

Hyrkas, E.K., Linscott, D.A. \& Rhudy, Jr., J.P. (2014). Evaluating preceptors' and preceptees' satisfaction concerning preceptorship and the preceptor-preceptee relationship. Journal of Nursing Education and Practice.

Kantar, L.D. (2014). Clinical Practice of New Nurse Graduates in Lebanon: Challenges and Perspectives Through the Eyes of Preceptors. , (November). 